\title{
Application of Central Composite Design and Artificial Neural Network for the Optimization of Fermentation Conditions for Lipase Production by Rhizopus arrhizus MTCC 2233
}

Aravindan Rajendran* and Viruthagiri Thangavelu

Biochemical Engineering Laboratory, Department of Chemical Engineering, Annamalai University, Annamalai Nagar- 608 002, Tamil Nadu, India

\begin{abstract}
The response surface optimization strategy was used to enhance the lipase production by Rhizopus arrhizus MTCC 2233 in submerged fermentation. Various vegetable oils were experimented as an inducer using the optimized medium to study the influence on lipase production, and corn oil was found to be the best inducer for lipase production by Rhizopus arrhizus. The optimization of fermentation conditions, temperature, initial $\mathrm{pH}$ and agitation speed was carried out using corn oil as the inducer. Statistical analysis of the experimental data showed that the temperature, agitation speed, quadratic effects of temperature, initial $\mathrm{pH}$ and agitation speed and interactive effects of temperature and agitation speed are significant parameters that affect lipase production. The optimum fermentation conditions were achieved at $32^{\circ} \mathrm{C} ; \mathrm{pH} 6.0$ and agitation speed of $107 \mathrm{rpm}$ with the maximum lipase activity of $4.32 \mathrm{U} / \mathrm{mL}$. Artificial neural network model was used to predict the lipase activity and cell mass production under various fermentation conditions. Unstructured kinetic models, Logistic model, Luedeking-Piret model and modified Luedeking-Piret model were used to describe the cell biomass, lipase production and glucose utilization kinetics respectively.
\end{abstract}

Keywords: Lipase fermentation; Response surface methodology; Cell cultures; Kinetics; Optimization

\section{Introduction}

Hydrolase enzymes play significant roles in biotechnology because of their extreme versatility with respect to substrate specificity and stereoselectivity [1-3]. Lipases [triacylglycerol acylhydrolases (EC 3.1.1.3)] are enzymes which catalyze the hydrolysis of fatty acid ester bonds in triacylglycerol to give free fatty acids, diacylglycerols, monoacylglycerols and glycerol at the lipid water interface [2]. Various microbial lipases have been purified, characterized and studied for their biotechnological applications in food, dairy, detergents, pharmaceuticals, textile, cosmetics \& paper industry, bioremediation of oil containing effluents and preparation of various flavor and fragrances as well [1-5]. Most of lipases produced commercially are currently obtained from fungi or yeasts [1-3]. Rhizopus, Aspergillus, Mucor, Geotrichum, Penicillium and Candida are the potential sources of commercial lipase production. The lipase from Rhizopus has 1,3-regioselectivity, for selectively catalyzing the hydrolysis of triacylglycerol [6]. However, the lipase production with Rhizopus sp. is relatively low-yield and economically unfavorable [6]. Various methods have been investigated in the literature to optimize the fermentation process to enhance lipase production yields, and most of literatures have reported improvement in lipase yield after optimization. Elibol and Ozer [7] optimized lipase production by Rhizopus arrhizus using response surface methodology and obtained $0.37 \mathrm{U} / \mathrm{mL}$ lipase activity (tributyrin as substrate). D'Annibale et al. [8] investigated the utilization of olive-mill wastewater as a growth medium for the microbial production of extra-cellular lipase using Rhizopus arrhizus NRRL 2286, Rhizopus sp. ISRIM 383 and Rhizopus oryzae NRRL 6431 and obtained a maximum lipase activity of $0.30,0.35$ and $0.36 \mathrm{IU} / \mathrm{mL}$ ( $\beta$-naftilmyristate as substrate) respectively. Repeated-batch-fermentation by immobilized $R$. arrhizus was conducted by Yang et al. [6] and observed that the lipase productivity increased from $3.1 \mathrm{U} / \mathrm{mL} \mathrm{h}$ in batch fermentation to $17.6 \mathrm{U} / \mathrm{mL} \mathrm{h}$ in repeated batch fermentation, which was 5.6 times as high as that in batch fermentation.

Screening and evaluation of nutritional and environmental re- quirements of microorganism are important steps for bioprocess development. Microbial lipase fermentations are significantly affected by the environmental conditions such as medium $\mathrm{pH}$, temperature, aeration, agitation and inoculation size. Response surface methodology (RSM) is a collection of experimental strategies, mathematical methods and statistical inference for constructing and exploring an approximate functional relationship between a response variable and a set of design variables $[9,10]$.

Due to the metabolic complexity of microorganisms, the development of rigorous models for a given biological reaction system based on physical and chemical parameters is still a challenge. This is mainly due to the non-linear nature of the biochemical networks and lack of complete knowledge $[11,12]$. Artificial neural network (ANN) methods have been utilized with great success for system design, modeling, prediction, optimization and control. This is mainly due to their capacity to learn, filter noisy signals and generalize information through training procedures [12]. Mathematical models of bioprocess kinetics facilitate data analysis and definitely provide a strategy for solving problems encountered in industrial fermentation processes $[13,14]$. The goal of the fermentation kinetic studies is to increase the productivity of batch process and to optimally design and operate continuous fermentation. Objectives of the present study are;

(i) Optimize the fermentation conditions such as $\mathrm{pH}$, tempera-

*Corresponding author: Aravindan Rajendran, Assistant Professor, Biochemical Engineering Laboratory, Department of Chemical Engineering, Annamalai University, Annamalai Nagar- 608 002, Tamil Nadu, India, Tel: 91-4144-238150 (R) 91-4144-239737 (O); Fax: 91- 4144- 238275 (O); E-mail: aravindraj@gmail.com

Received January 10, 2012; Accepted March 05, 2012; Published March 07 2012

Citation: Rajendran A, Thangavelu V (2012) Application of Central Composite Design and Artificial Neural Network for the Optimization of Fermentation Conditions for Lipase Production by Rhizopus arrhizus MTCC 2233. J Bioprocess Biotechniq 2:118 doi: 10.4172/2155-9821.1000118

Copyright: (C 2012 Rajendran A, et al. This is an open-access article distributed under the terms of the Creative Commons Attribution License, which permits unrestricted use, distribution, and reproduction in any medium, provided the original author and source are credited. 
ture and agitation speed for lipase production by Rhizopus arrhizus using RSM in an optimized medium

(ii) Utilize the ANN model for the prediction of lipase activity and cell biomass at various conditions

(iii) Predict lipase fermentation kinetics using unstructured kinetic models.

\section{Materials and Methods}

\section{Materials}

The medium components and other chemicals used were procured from Himedia Ltd, Mumbai, India. All chemicals used were of analytical grade unless otherwise specified. The orbital shaker is a make of Remi Laboratories India, RIS - 24 BL; centrifuge from Remi Laboratories India, C-24 BL; homogenizer from Global-Butterfly India, 230V $\mathrm{AC}, 550 \mathrm{~W}$ heavy duty and the spectrophotometer is a make of Elico India Ltd., (Double Beam UV-VIS Spectrophotometer-SL 164).

\section{Microorganisms and culture maintenance}

Rhizopus arrhizus MTCC 2233 was obtained from Microbial Type Culture Collection of gene bank (MTCC), Institute of Microbial Technology, Chandigarh, India. The Rhizopus arrhizus stock culture was maintained on potato dextrose agar slants containing potato infusion (infusion from $200 \mathrm{~g}$ potatoes) $4.0 \mathrm{~g} / \mathrm{L}$; Dextrose $20.0 \mathrm{~g} / \mathrm{L}$. Spirit blue agar (Himedia-Mumbai, India) was used for the detection of lipolytic activity of the microorganisms.

\section{Submerged batch fermentation}

The $R$. arrhizus MTCC 2233 slant was kept at $30^{\circ} \mathrm{C}$ for 2 days. After growth and sporulation, $10 \mathrm{~mL}$ sterile distilled water was aseptically added to the agar slant which was then scraped to release the spores. The spore suspension was centrifuged at $2500 \mathrm{~g}$ for $10 \mathrm{~min}$ and, supernatant was discarded and then the spores were resuspended in $1 \mathrm{~mL}$ of sterile distilled water. Spore suspension $(1 \mathrm{~mL})$ was used as inoculum for $250 \mathrm{~mL}$ shake flask containing $100 \mathrm{~mL}$ of fermentation medium (glucose- $15 \mathrm{~g} / \mathrm{L}$; oil inducer $-10 \mathrm{~mL} / \mathrm{L}$; peptone- $6 \mathrm{~g} / \mathrm{L}$; yeast extract- $6 \mathrm{~g} / \mathrm{L} ; \mathrm{K}_{2} \mathrm{HPO}_{4}-0.1 \mathrm{~g} / \mathrm{L} ; \mathrm{KH}_{2} \mathrm{PO}_{4}-2 \mathrm{~g} / \mathrm{L} ; \mathrm{CaCl}_{2} .2 \mathrm{H}_{2} \mathrm{O}-1 \mathrm{~g} / \mathrm{L}$; $\mathrm{MgSO}_{4} .7 \mathrm{H}_{2} \mathrm{O}-0.5 \mathrm{~g} / \mathrm{L} ; \mathrm{ZnSO}_{4}-0.01 \mathrm{~g} / \mathrm{L} ; \mathrm{FeSO}_{4} .7 \mathrm{H}_{2} \mathrm{O}-0.05 \mathrm{~g} / \mathrm{L} ; \mathrm{CuSO}_{4}-$ $\left.0.02 \mathrm{~g} / \mathrm{L} ; \mathrm{MnSO}_{4} \cdot \mathrm{H}_{2} \mathrm{O}-0.02 \mathrm{~g} / \mathrm{L}\right)$. After the inoculation, flasks were placed on a rotary shaker at $30^{\circ} \mathrm{C}$ and $120 \mathrm{rpm}$ incubated for 2 days and were then used to inoculate the production medium at $5 \%(\mathrm{v} / \mathrm{v})$ level. The lipase production by $R$. arrhizus was studied in $250 \mathrm{~mL}$ Erlenmeyer flask with $100 \mathrm{~mL}$ of the production medium. The $\mathrm{pH}$ of fermentation medium was adjusted using $2 \mathrm{M} \mathrm{NH}_{4} \mathrm{OH}$ and sterilized at $121^{\circ} \mathrm{C}$ (15 psi) for $20 \mathrm{~min}$. The flasks were incubated in an orbital shaker at constant agitator speed and temperature for the fermentation period of $108 \mathrm{~h}$. Identical flasks were used for the fermentation and the cells were separated from the medium by centrifugation at $5000 \mathrm{~g}$ for $15 \mathrm{~min}$. The clear supernatant was used for the analysis of lipase activity, protease activity, total soluble protein and glucose. All the submerged batch fermentations were conducted in triplicate and average results were given in this report. Lipase production was measured and compared at different conditions.

\section{Lipase activity assay}

Lipase activity was estimated with olive oil emulsion by the procedure of Ota and Yamada [15]. Olive oil emulsion was prepared by homogenizing $25 \mathrm{~mL}$ of olive oil and $75 \mathrm{~mL}$ of $2 \%$ w/v polyvinyl alcohol solution in a homogenizer for $6 \mathrm{~min}$ at $20000 \mathrm{rpm}$. The reaction mixture composed of $2 \mathrm{~mL}$ olive oil emulsion, $2.5 \mathrm{~mL} 0.05 \mathrm{M}$ phosphate buffer and $0.5 \mathrm{~mL}$ enzyme solution was incubated at $37^{\circ} \mathrm{C}$ for $15 \mathrm{~min}$. The emulsion was disrupted by addition of $10 \mathrm{~mL}$ acetone immediately after $15 \mathrm{~min}$ incubation and the liberated fatty acids content was titrated against $0.05 \mathrm{~N} \mathrm{NaOH}$. One unit (U) of lipase activity was defined as $1 \mu$ mole of free fatty acids liberated per $\mathrm{mL}$ of enzyme per minute at $37^{\circ} \mathrm{C}$.

\section{Protease activity assay}

The protease activity was assayed by modified Anson method [16] using casein as the substrate. $2 \mathrm{~mL}$ of $1 \% \mathrm{w} / \mathrm{v}$ casein solution is mixed with $0.5 \mathrm{~mL}$ of enzyme solution and incubated at $37^{\circ} \mathrm{C}$ for $30 \mathrm{~min}$ and reaction was quenched by addition of $2.5 \mathrm{~mL}$ of $0.4 \mathrm{M}$ trichloroacetic acid to the reaction solution. The solution with precipitate was filtered and to the $1 \mathrm{~mL}$ of filtrate, $5 \mathrm{~mL}$ of $0.4 \mathrm{M} \mathrm{Na}_{2} \mathrm{CO}_{3}$ and $0.5 \mathrm{~mL}$ of folin reagent were added. After $10 \mathrm{~min}$ of incubation at $37^{\circ} \mathrm{C}$, the colour intensity was measured at $660 \mathrm{~nm}$. One unit (U) of protease activity was defined as $1 \mu$ gram of tyrosine liberated per minute by $1 \mathrm{~mL}$ of enzyme at $37^{\circ} \mathrm{C}$.

\section{Biomass, glucose and protein determination}

The biomass concentration (dry cell weight) was determined by gravimetric method. The glucose concentration in the cultivation broth was determined as described by Miller [17] using dinitrosalicylic acid. The total soluble protein in the medium was determined as described by Lowry et al. [18].

\section{Central Composite Experimental Design (CCD)}

An orthogonal (2) factorial central composite experimental design with six star points and six replicates at the centre with a total of 20 experiments were used to optimize the fermentation conditions such as temperature, medium $\mathrm{pH}$ and agitation speed [19-22]. These conditions were tested at five coded levels, $-1.682,-1,0,+1$ and +1.682 . The experimental range and levels of the three fermentation conditions used in RSM in terms of coded levels and actual values and the CCD experimental plan were given in Table 1 . The CCD experiment was designed using the MINITAB software package, version 14.0, The Math Works Inc. The variables were coded according to the following equation,

$$
x_{i}=\frac{X_{i}-X_{c}}{\Delta X_{i}}, \mathrm{i}=1,2,3 \ldots \mathrm{k} .
$$

Where, is the coded value of an independent variable, $\mathrm{X}_{\mathrm{i}}$ is the real value of an independent variable, $X_{c}$ the real value of an independent variable at the center point and $\Delta \mathrm{X}_{\mathrm{i}}$ is the step change value. Multiple regression analysis of the experimental data gives the second order polynomial equation for optimization of variables. The behaviour of the system was explained by the following second degree polynomial equation,

$$
\mathrm{Y}=\beta_{0}+\Sigma \beta_{\mathrm{i}} x_{\mathrm{i}}+\Sigma \beta_{\mathrm{ii}} x_{i}^{2}+\Sigma \beta_{\mathrm{ij}} x_{\mathrm{i}} x_{\mathrm{j}}
$$

Where, $\mathrm{Y}$ is the predicted response, $\beta_{0}$ the offset term, $\beta_{\mathrm{i}}$ the coefficient linear effect, $\beta_{\mathrm{ii}}$ the coefficient squared effect and $\beta_{\mathrm{ij}}$ the coefficient of interaction effect. The MINITAB software statistical program package was used for regression analysis of the experimental data obtained and to estimate the coefficients of the regression equation. The response surface plots were used to describe the individual and cumulative effects of the variables as well as the interactions between the variables on the lipase activity. The second degree polynomial equation was maximized by a constraint search procedure to obtain the optimal levels of the independent variables and the predicted maximum lipase activity. 


\section{Artificial Neural Network Model (ANN)}

The feed forward back-propogation algorithm with one hidden layer was used in the training of the neural network, based on varying input/output pair data sets. ANN was applied for the purpose of simulation on the same experimental data (Table 1) used for RSM. The accuracy of the neural network prediction is dependent on the training patterns as well as the structure of the neural network [23]. Neural network consist of many processing elements called neurons interconnected by information channels. The number of neurons in the input and output layers are given by the number of input and output variables in the fermentation process. The input signals are amplified or dampened by a weight associated with each information channel. The neuron then sums all weighted inputs and passes them through a threshold to determine the activation value (the fired output signal) of this neuron. The inter neuron activity can be modeled by an activation function [24]. Sigmoid activation function which is commonly used in back propagation algorithm is given below,

$$
\mathrm{y}_{j}=-\left[1+\exp \left(\sum_{i=1}^{n} a_{i} w_{i j}+\theta_{j}\right)\right]^{-1}
$$

Where, $a_{i}$ - input signal, $y_{j}$ - fired output signal, $w_{i j}$-weight associated with the input signal ai, $\theta j$ - threshold value of neuron $j$.

In back propagation networks, the process is executed according to an error feedback method by which it will first update the values of all the neurons corresponding to input data based on current weights and then adjust the weights according to the error between fixed outputs and desired outputs to reduce the error. The summation of output errors, $\mathrm{E}$ is given by,

$$
\mathrm{E}=\frac{1}{2} \sum_{j}\left(y_{j}-d_{j}\right)^{2}
$$

Where, $d_{j}$ is the desired output from neuron $j$. A common scheme used for neural network training is the maximum gradient scheme, in which each connection weight $\mathrm{w}_{\mathrm{ik}}$ was changed by $\Delta \mathrm{w}_{\mathrm{ik}}$ as given below,

$$
\Delta \mathrm{w}_{\mathrm{ik}}=-\eta \frac{\partial E}{\partial w_{i k}}
$$

Where, $\eta$ is the positive constant controlling the speed of learning. The Neural network toolbox in MATLAB software was used to construct the ANN topology. This topology of neural network was used in this study for the prediction of the lipase activity and cell mass under various environmental conditions.

\section{Unstructured Model Development for Fermentation Kinetics}

Various unstructured models were proved to be sufficient for characterizing the fermentation kinetics. In an unstructured model the cellular representations are single component representations $[13,25,26]$. The exponential growth phase can be characterized by the following first order equation which states that the rate of increase of cell biomass is proportional to the quantity of viable cell biomass at any instant time,

$\frac{d X}{d t}=\mu X$

Where, $\mathrm{dX} / \mathrm{dt}$ is the growth rate $(\mathrm{g} / \mathrm{L} \cdot \mathrm{h}) ; \mathrm{X}$ is the concentration of biomass $(\mathrm{g} / \mathrm{L}) ; \mu$ is the specific cell growth rate $(1 / \mathrm{h})$. The growth of cell is governed by a hyperbolic relationship and there is a limit to the maximum attainable cell biomass concentration. Such growth kinetics is described by logistic equation [25] as,

$$
\frac{d X}{d t}=\mu_{0}\left(1-\frac{X}{X_{\max }}\right) \mathrm{X}
$$

Where $\mu_{0}$ is the initial specific growth rate $(1 / \mathrm{h})$ and $X_{\max }$ is the maximum cell mass concentration $(\mathrm{g} / \mathrm{L})$. Equation (7) on integration using $\mathrm{X}_{0}=\mathrm{X}(\mathrm{t}=0)$ gives a sigmoidal variation $\mathrm{X}(\mathrm{t})$ that may empirically represent both an exponential and a stationary phase.

\begin{tabular}{|c|c|c|c|c|c|c|c|c|c|c|}
\hline \multirow{2}{*}{$\begin{array}{l}\text { Run } \\
\text { No. }\end{array}$} & \multicolumn{3}{|c|}{$\begin{array}{l}\text { CCD Experimental Design matrix (Coded } \\
\text { and real values) }\end{array}$} & \multicolumn{3}{|c|}{ Experimental } & \multicolumn{2}{|c|}{$\begin{array}{l}\text { Predicted Lipase } \\
\text { activity }\end{array}$} & \multicolumn{2}{|c|}{$\begin{array}{l}\text { Predicted } \\
\text { Cell mass }\end{array}$} \\
\hline & $\mathbf{x}_{1}$ & $x_{2}$ & $x_{3}$ & $\begin{array}{c}\text { Cell massa } \\
\left(\mathrm{g} \mathrm{l}^{-1}\right)\end{array}$ & $\begin{array}{l}\text { Lipase activityb } \\
\qquad\left(\mathrm{U} \mathrm{ml} \mathrm{ml}^{-1}\right)\end{array}$ & $\begin{array}{c}\text { Protease activi- } \\
\text { tyc } \\
\left(\mathrm{U} \mathrm{ml}^{-1}\right)\end{array}$ & RSM (U ml-1) & ANN $\left(\mathrm{U} \mathrm{ml}^{-1}\right)$ & $\operatorname{RSM}\left(\mathrm{g} \mathrm{l}^{-1}\right)$ & ANN $\left(\mathrm{g} \mathrm{l}^{-1}\right)$ \\
\hline 1 & $-1(28)$ & $-1(5)$ & $-1(120)$ & 4.20 & 2.15 & 0.95 & 1.969 & 2.15 & 4.432 & 4.2 \\
\hline 2 & $1(32)$ & $-1(5)$ & $-1(120)$ & 6.56 & 3.00 & 1.65 & 3.36 & 3.0 & 6.807 & 6.56 \\
\hline 3 & $-1(28)$ & $1(6.5)$ & $-1(120)$ & 3.15 & 2.20 & 1.05 & 2.052 & 2.2 & 3.159 & 3.15 \\
\hline 4 & $1(32)$ & $1(6.5)$ & $-1(120)$ & 5.82 & 3.8 & 0.45 & 3.518 & 3.8 & 5.499 & 5.82 \\
\hline 5 & $-1(28)$ & $-1(5)$ & $1(160)$ & 3.30 & 1.90 & 0.85 & 1.975 & 1.9 & 3.772 & 3.3 \\
\hline 6 & $1(32)$ & $-1(5)$ & $1(160)$ & 3.65 & 2.25 & 1.95 & 2.191 & 2.25 & 3.792 & 3.65 \\
\hline 7 & $-1(28)$ & $1(6.5)$ & $1(160)$ & 3.12 & 2.65 & 0.65 & 2.083 & 2.65 & 3.024 & 3.12 \\
\hline 8 & $1(32)$ & $1(6.5)$ & $1(160)$ & 3.09 & 2.40 & 1.26 & 2.374 & 2.4 & 3.008 & 3.09 \\
\hline 9 & $-1.682(26.6)$ & $0(5.75)$ & $0(140)$ & 2.60 & 1.20 & 0.55 & 1.588 & 1.2 & 2.305 & 2.6 \\
\hline 10 & $1.682(33.3)$ & $0(5.75)$ & $0(140)$ & 4.21 & 3.10 & 2.15 & 3.003 & 3.1 & 4.29 & 4.21 \\
\hline 11 & $0(30)$ & $-1.682(4.46)$ & $0(140)$ & 5.81 & 2.60 & 0.88 & 2.383 & 2.6 & 5.232 & 5.81 \\
\hline 12 & $0(30)$ & $1.682(7.01)$ & $0(140)$ & 3.14 & 2.10 & 0.45 & 2.607 & 2.1 & 3.503 & 3.14 \\
\hline 13 & $0(30)$ & $0(5.75)$ & $-1.682(106.4)$ & 6.41 & 3.20 & 1.65 & 3.249 & 3.2 & 6.382 & 6.41 \\
\hline 14 & $0(30)$ & $0(5.75)$ & $1.682(173.6)$ & 3.92 & 2.05 & 1.65 & 2.292 & 2.05 & 3.733 & 3.92 \\
\hline 15 & $0(30)$ & $0(5.75)$ & $0(140)$ & 5.20 & 4.10 & 2.15 & 3.841 & 3.925 & 5.139 & 5.133 \\
\hline 16 & $0(30)$ & $0(5.75)$ & $0(140)$ & 4.92 & 3.70 & 1.95 & 3.841 & 3.925 & 5.139 & 5.133 \\
\hline 17 & $0(30)$ & $0(5.75)$ & $0(140)$ & 4.56 & 4.20 & 1.89 & 3.841 & 3.925 & 5.139 & 5.133 \\
\hline 18 & $0(30)$ & $0(5.75)$ & $0(140)$ & 5.95 & 3.85 & 2.30 & 3.841 & 3.925 & 5.139 & 5.133 \\
\hline 19 & $0(30)$ & $0(5.75)$ & $0(140)$ & 4.85 & 3.90 & 1.65 & 3.841 & 3.925 & 5.139 & 5.133 \\
\hline 20 & $0(30)$ & $0(5.75)$ & $0(140)$ & 5.32 & 3.80 & 2.01 & 3.841 & 3.925 & 5.139 & 5.133 \\
\hline
\end{tabular}

$$
X(t)=\frac{X_{0} e^{\mu_{0} t}}{1-\left(\frac{X_{0}}{X_{\max }}\right)\left(1-e^{\mu_{0} t}\right)}
$$

The kinetic parameter, $\mu_{0}$ in this equation is determined by rear-

$\mathrm{I}_{1}$ : Temperature; $x_{2}$ : Initial $\mathrm{pH} ; x_{3}$ : Agitation speed

$\mathrm{a}, \mathrm{b}, \mathrm{c}$ The maximum values of cell mass, lipase activity and protease activity respectively and they are the mean values of triplicates. $250 \mathrm{ml}$ Erlenmeyer flask containing 100 $\mathrm{ml}$ production medium (constant) was incubated in an orbital shaker (variable) for the fermentation period of $48 \mathrm{hrs}$.

Table 1: Central composite experimental design and comparison of experimental values with RSM and ANN predicted values of lipase activity using R. arrhizus in submerged fermentation methods. 
ranging equation (8) as,

$$
\mu_{0} t=\ln \left[\frac{X_{\max }}{X_{0}}-1\right]+\ln \left[\frac{\bar{X}}{1-\bar{X}}\right]
$$

Where $\bar{X}=\frac{X}{X_{\max }}$, if the logistic equation describes the data suitably, then a plot of $\ln \left[\frac{\bar{X}}{1-\bar{X}}\right]$ vs. t should give a straight line of slope ' $\mu_{0}$ ' and intercept $-\ln \left[\left(\frac{X_{\max }}{X_{0}}-1\right)\right]$

The kinetics of lipase production was described by Luedeking-Piret equation [27] which states that the product formation rate depends upon both the instantaneous biomass concentration (X) and growth rate $(\mathrm{dX} / \mathrm{dt})$ in a linear fashion.

$$
\frac{d P}{d t}=\alpha \frac{d X}{d t}+\beta X
$$

where $\alpha(\mathrm{gP} / \mathrm{gX})$ and $\beta(\mathrm{gP} / \mathrm{gX} \bullet \mathrm{h})$ are empirical constants that may vary with fermentation conditions. Integrating equation (10) using equation (7),

$$
\mathrm{P}_{\mathrm{t}}=\mathrm{P}_{0}+\alpha \mathrm{A}(\mathrm{t})+\beta \mathrm{B}(\mathrm{t})
$$

Where $\mathrm{P}_{0}$ and $\mathrm{P}_{t}$ are the product concentrations at initial time and at any time (at time t) respectively and,

$$
\begin{aligned}
& \mathrm{A}(\mathrm{t})=X_{0}\left[\frac{e^{\mu_{0} t}}{1-\left(\frac{X_{0}}{X_{\text {max }}}\right)\left(1-e^{\mu_{0} t}\right)}-1\right] \\
& \mathrm{B}(\mathrm{t})=\frac{X_{\max }}{\mu_{0}} \ln \left[1-\frac{X_{0}}{X_{\text {max }}}\left(1-e^{\mu_{0} t}\right)\right]
\end{aligned}
$$

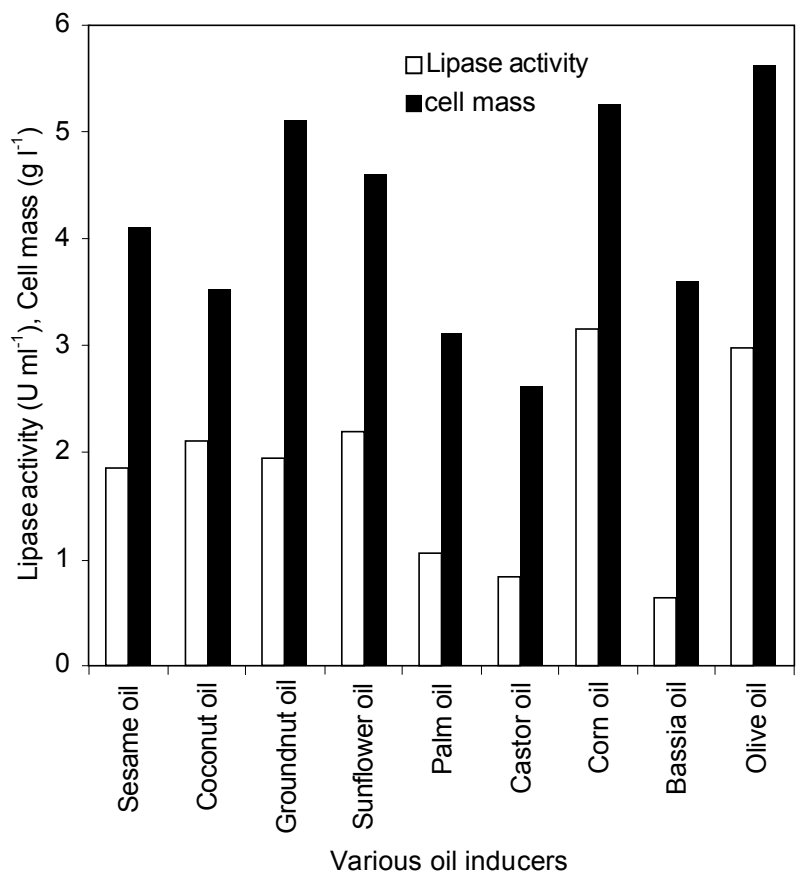

Figure 1: Effect of inducers on lipase production by $R$. arrhizus in submerged fermentation
The parameters $\alpha$ and $\beta$ in equation (11) are determined by plotting $-\mathrm{P}_{0} / \mathrm{B}(\mathrm{t}) \mathrm{vs}$

$\mathrm{A}(\mathrm{t}) / \mathrm{B}(\mathrm{t})$ which is a straight line with slope ' $\alpha$ ' and intercept ' $\beta$ '.

The substrate utilization kinetics is given by the following equation, which considers substrate conversion to cell mass, to product and substrate consumption for maintenance [25].

$\frac{d S}{d t}=-\frac{1}{Y_{X / S}} \frac{d X}{d t}-\frac{1}{Y_{P / S}} \frac{d P}{d t}-k_{e} X$

Where, $\mathrm{Y}_{\mathrm{X} / \mathrm{S}}$ and $\mathrm{Y}_{\mathrm{P} / \mathrm{S}}$ are yields of cell mass and product with respect to substrate and $\mathrm{K}_{\mathrm{e}}$ is the maintenance coefficient for cells. Rearranging the substrate material balance equation (14),

$$
\frac{d S}{d t}=-\gamma \frac{d X}{d t}-\eta X
$$

Where,

$$
\begin{aligned}
& \gamma(\mathrm{gS} / \mathrm{gX})=\frac{1}{Y_{X / S}^{\prime}}+\frac{\alpha}{Y_{P / S}^{\prime}} \\
& \eta(g S / g X . h)=\frac{\beta}{Y_{P / S}^{\prime}}+k_{e}
\end{aligned}
$$

Equation (15) is the modified Luedeking- Piret equation for substrate utilization kinetics.

Substituting for $\mu$ from equation (7) and integrating gives

$$
\mathrm{S}_{\mathrm{t}}=\mathrm{S}_{0}-\gamma \mathrm{m}(\mathrm{t})-\eta \mathrm{n}(\mathrm{t})
$$

Where, $\mathrm{S}_{0}$ and $\mathrm{S}_{\mathrm{t}}$ are the substrate concentrations at initial time and at anytime ' $\mathrm{t}$ ' respectively and,

$$
\begin{aligned}
& \mathrm{m}(\mathrm{t})=X_{0}\left[\frac{e^{\mu_{0} t}}{1-\left(\frac{X_{0}}{X_{m}}\right)\left(1-e^{\mu_{0} t}\right)}-1\right] \\
& \mathrm{n}(\mathrm{t})=\frac{X_{m}}{\mu_{0}} \ln \left[1-\frac{X_{0}}{X_{m}}\left(1-e^{\mu_{0} t}\right)\right]
\end{aligned}
$$

Kinetic parameters $(\gamma, \eta)$ in equation (18) is determined by plotting $\frac{S_{0}-S_{t}}{n(t)} v s \frac{m(t)}{n(t)}$ which is a straight line with slope $\gamma$ and intercept $\eta$.

\section{Results and Discussion}

\section{Optimization of inducer}

Lipase production by Rhizopus arrhizus was experimented in submerged batch culture in shake flasks. In the first step, the medium components that have the more influence on the lipase production were identified using Plackett-Burman (PB) statistical experimental design. The statistical analysis of $\mathrm{PB}$ design (data not presented) showed that, the medium components such as olive oil, peptone, $\mathrm{CaCl}_{2} \cdot 2 \mathrm{H}_{2} \mathrm{O}$ and $\mathrm{MgSO}_{4} \cdot 7 \mathrm{H}_{2} \mathrm{O}$ were found to have the most profound influence on the lipase production with a confidence level of more than $95 \%$.

The composition of culture medium, in particular addition of different lipid substances can result in the production of different isoenzymes and oils play a vital role in the lipase synthesis [28]. The oils mainly contain various proportions of three main types of fatty acids such as saturated, monounsaturated and polyunsaturated fatty acids in addition to vitamins and growth factors. The basic constituents of vege- 


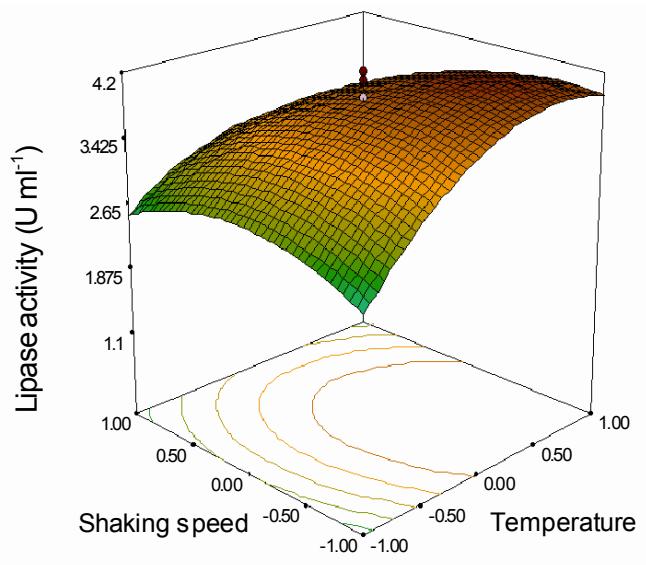

(A)

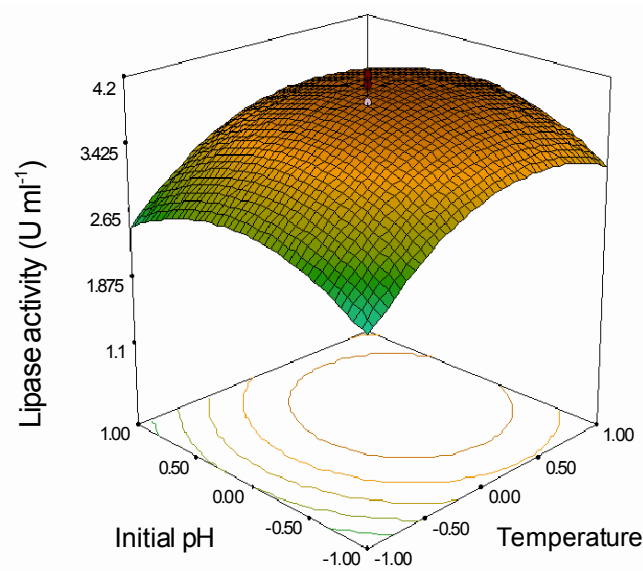

(B)

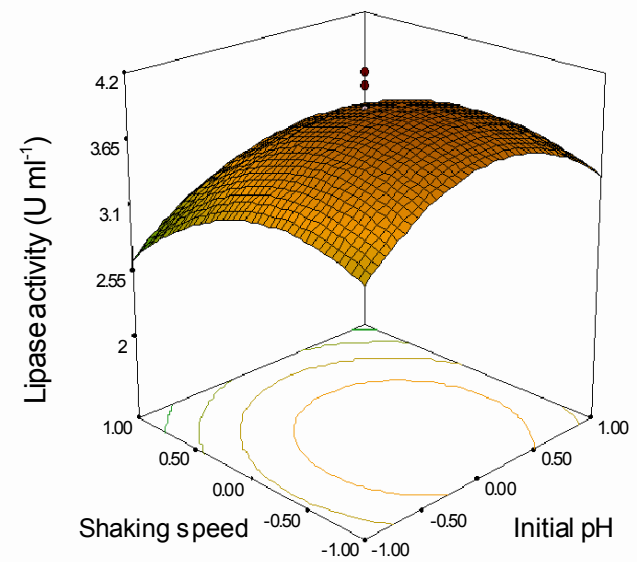

(C)

Figure 2: Response surface plot and contour plots showing the effects of $(\mathrm{A})$ temperature and agitation speed, (B) temperature and initial $\mathrm{pH}$, (C) initial $\mathrm{pH}$ and agitation speed, on lipase production by R. arrhizus with the remaining factors kept constant at the middle level of the central composite experimental design.

table oils are 16-carbon acids (palmitic and palmitoleic) and 18-carbon acids (stearic, oleic, linoleic and linolenic). The effect of vegetable oils on lipase production was studied by single factor optimization method keeping all other media constituents and process conditions constant. The optimized medium used for the inducer optimization studies which contains glucose- $15 \mathrm{~g} / \mathrm{L}$; peptone- $6 \mathrm{~g} / \mathrm{L}$; yeast extract- $6 \mathrm{~g} / \mathrm{L}$; $\mathrm{K}_{2} \mathrm{HPO}_{4}-0.1 \mathrm{~g} / \mathrm{L} ; \mathrm{KH}_{2} \mathrm{PO}_{4}-2 \mathrm{~g} / \mathrm{L} ; \mathrm{CaCl}_{2} .2 \mathrm{H}_{2} \mathrm{O}-1 \mathrm{~g} / \mathrm{L} ; \mathrm{MgSO}_{4} .7 \mathrm{H}_{2} \mathrm{O}-0.5$ $\mathrm{g} / \mathrm{L} ; \mathrm{ZnSO}_{4}-0.01 \mathrm{~g} / \mathrm{L} ; \mathrm{FeSO}_{4} .7 \mathrm{H}_{2} \mathrm{O}-0.05 \mathrm{~g} / \mathrm{L} ; \mathrm{CuSO}_{4}-0.02 \mathrm{~g} / \mathrm{L} ; \mathrm{MnSO}_{4}$ $. \mathrm{H}_{2} \mathrm{O}-0.02 \mathrm{~g} / \mathrm{L}$ and various vegetable oil inducers at the concentration of $10 \mathrm{~mL} / \mathrm{L}$. The vegetable oils used in this study were sesame oil, coconut oil, groundnut oil, castor oil, palm oil, sunflower oil, corn oil, bassia oil and olive oil. Among all oil inducers tested in this study, corn oil was found to be the best inducer for lipase production by Rhizopus arrhizus followed by sunflower oil, coconut oil, groundnut oil, olive oil, sesame oil, palm oil, castor oil, and bassia oil (Figure 1). Maximum lipase activity of $3.15 \mathrm{U} / \mathrm{mL}$ was observed at $84 \mathrm{~h}$ of cultivation using corn oil as an inducer. Elibol and Ozer have also reported similar results for the lipase production by Rhizopus arrhizus using corn oil [7].

\section{Central Composite Experimental Design and Optimi- zation of Fermentation Conditions by Response Sur- face Methodology}

The experimental plan to determine the optimum combination of fermentation conditions for enhancing the lipase production was done using CCD and results are presented in Table 1 along with experimental and predicted values using RSM and ANN. The production medium used for the optimum fermentation conditions contain: glucose- 15 $\mathrm{g} / \mathrm{L}$; corn oil-10 mL/L; peptone- $6 \mathrm{~g} / \mathrm{L}$; yeast extract- $6 \mathrm{~g} / \mathrm{L} ; \mathrm{K}_{2} \mathrm{HPO}_{4}-0.1$ $\mathrm{g} / \mathrm{L} ; \mathrm{KH} 2 \mathrm{PO} 4-2 \mathrm{~g} / \mathrm{L} ; \mathrm{CaCl}_{2} \cdot 2 \mathrm{H}_{2} \mathrm{O}-1 \mathrm{~g} / \mathrm{L} ; \mathrm{MgSO}_{4} .7 \mathrm{H}_{2} \mathrm{O}-0.5 \mathrm{~g} / \mathrm{L} ; \mathrm{ZnSO}_{4}^{-}$ $0.01 \mathrm{~g} / \mathrm{L} ; \mathrm{FeSO}_{4} .7 \mathrm{H}_{2} \mathrm{O}-0.05 \mathrm{~g} / \mathrm{L} ; \mathrm{CuSO}_{4}-0.02 \mathrm{~g} / \mathrm{L} ; \mathrm{MnSO}_{4} . \mathrm{H}_{2} \mathrm{O}-0.02$ $\mathrm{g} / \mathrm{L}$.

Multiple regression analysis of the experimental data obtained using CCD for lipase production gave the following second order polynomial equation (21),

$$
\begin{aligned}
& Y_{1}=3.9165+0.4207 x_{1}+0.0666 x_{2}-0.2844 x_{3}-0.5721 x_{1}^{2}-0.5014 x_{2}^{2}- \\
& 0.4042 x_{3}^{2}+0.0187 x_{1} x_{2}-0.2938 x_{1} x_{3}+0.0062 x_{2} x_{3}
\end{aligned}
$$

where $\mathrm{Y}_{1}$ is the lipase activity and $\mathrm{x}_{1}, \mathrm{x}_{2}$ and $\mathrm{x}_{3}$ are the coded values of the independent variables, temperature, $\mathrm{pH}$ and agitation speed respectively.

The experimental results were analyzed using Minitab statistical software and the correlation coefficient $(\mathrm{R})$, determination coefficient $\left(\mathrm{R}^{2}\right)$ and adjusted determination coefficient (Adj $\left.\mathrm{R}^{2}\right)$ was determined to check the competence of polynomial model. The value of $\mathrm{R}$ is 0.956 which implies a high degree of correlation between the observed and 


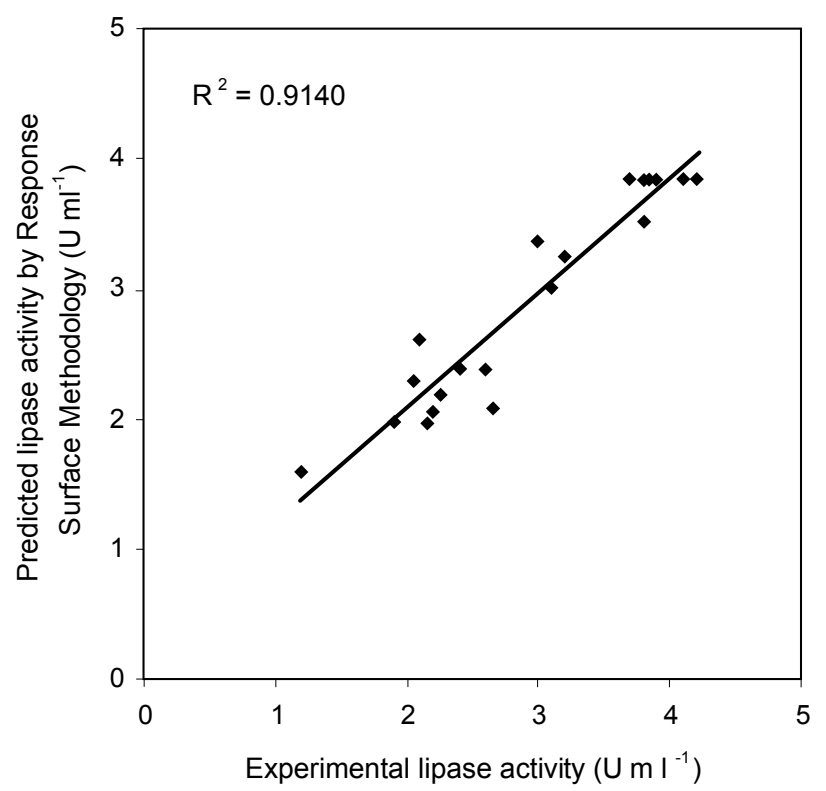

(A)

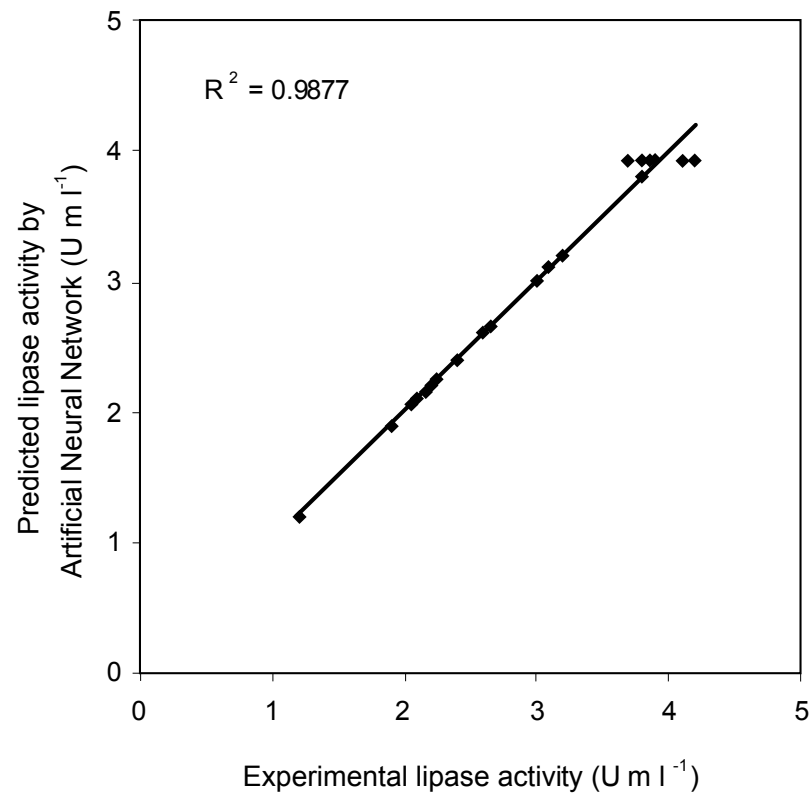

(B)

Figure 3: (A) Comparison of experimental and response surface methodology model predicted values of lipase activity by $R$. arrhizus (B) Comparison of experimental and artificial neural network model predicted values of lipase activity by $R$. arrhizus.

predicted values. The $\mathrm{R}^{2}$ value is 0.914 suggests that only about $8.6 \%$ of the total variations are not explained by the model. The adj $\mathrm{R}^{2}$ corrects the $\mathrm{R}^{2}$ value for the sample size and the number of terms in the model. If there are many terms in the model and the sample size is not very large, the adjusted $\mathrm{R}^{2}$ may be noticeably smaller than the $\mathrm{R}^{2}$. The adjusted $R^{2}$ in this study was 0.837 which is close to $R^{2}$ value which indicates the better prediction of the model.

Statistical testing of the model was carried out using analysis of variance (ANOVA) technique, which is required to test the significance and adequacy of the model. The ANOVA of the regression model demonstrates that the model is highly significant as evident from the calculated $\mathrm{F}$ value (Explained variance / unexplained variance; $\mathrm{F}_{\text {model }}=11.84$ ) and a very low probability value $\left(\mathrm{P}_{\text {model }}>\mathrm{F}=0\right)$. Moreover the computed $\mathrm{F}$ value is much greater than the tabulated $\mathrm{F}$ value $\left(\mathrm{F}_{9,10}=3.02\right.$ at $5 \%$ significance level) indicating that the treatment differences are highly significant. The Model F-value of 11.27 implies the model is significant. The students-t-distribution and the corresponding $\mathrm{P}$ values, along with parameter estimates for lipase activity was evaluated using MINITAB software. The $\mathrm{P}$ value signifies that the coefficient for the linear effect of temperature and agitation speed, the quadratic effects of temperature, $\mathrm{pH}$ and agitation speed and the interactive effects of temperature and agitation speed are significant. The regression equation was solved using MATLAB software and the optimal values of the test variables in the coded units were found to be $\mathrm{x}_{1}=0.504, \mathrm{x}_{2}=0.078, \mathrm{x}_{3}=-0.533$ and the corresponding uncoded values were $\mathrm{x}_{1}=31^{\circ} \mathrm{C}, \mathrm{x}_{2}(\mathrm{pH})=5.80, \mathrm{x}_{3}=$ $129.3 \mathrm{rpm}$ with a predicted maximum lipase activity of $4.101 \mathrm{U} / \mathrm{mL}$. The normal probability plot of the residuals is an important diagnostic tool to detect and explain the departures from the assumptions that errors are normally distributed, independent of each other and the error variances are homogenous. An excellent normal distribution confirmed the normality assumption and the independence of the residuals. The residual plot shows equal scatter of the residual data above and below the $\mathrm{x}$ - axis indicating that the variance was independent of the value of the lipase production and thus supporting the adequacy of the least square fit.

The response surfaces obtained using the MINITAB software were shown in Figure 2 for lipase production and the figures express the significance of various fermentation conditions. The shapes of the response surfaces may be circular or elliptical indicating the significance of the interactions between the variables. The elliptical nature of the contour plots between the conditions temperature and agitation speed indicates that the interaction between these set of variables has a significant effect on lipase yield. Comparison of experimental and RSM model predicted values of lipase activity and the comparison of experimental and ANN model predicted values of lipase activity by $R$. arrhizus is shown in Figures 3A \& 3B respectively.

Figure 4 illustrates the main effects plot of mean lipase activity with the fermentation conditions temperature, $\mathrm{pH}$ and agitation speed. The mean lipase activity was high at the center of the experimental range of temperature, $\mathrm{pH}$ and agitation speed. Further increase in the variables causes a decrease in lipase activity. The mean lipase activity was very low at the lowest temperature setting $\left(26.6^{\circ} \mathrm{C}\right)$ when compared to the other factor settings. The mean lipase activity was high $(3.2 \mathrm{U} / \mathrm{mL})$ at the lowest level of the agitation speed (106 rpm) when compared to the tested higher levels $(173 \mathrm{rpm})$. Probably at lower agitation speed the microorganism may attain its complete morphological structure for high extracellular lipase secretion.

An experiment was conducted at the optimized fermentation conditions determined by RSM to confirm the predicted optimum response. The maximum lipase activity of $4.32 \mathrm{U} / \mathrm{mL}$ was obtained at 72 $\mathrm{h}$ of cultivation and illustrated in Figure 5. The experimental and the predicted values of enzyme activity showed good agreement with one another with high degree of accuracy of the model substantiating the model validation under the experimental conditions. The lipase production was found to increase gradually after the $24 \mathrm{~h}$ of the fermentation period when the growth of microorganisms reached the early 


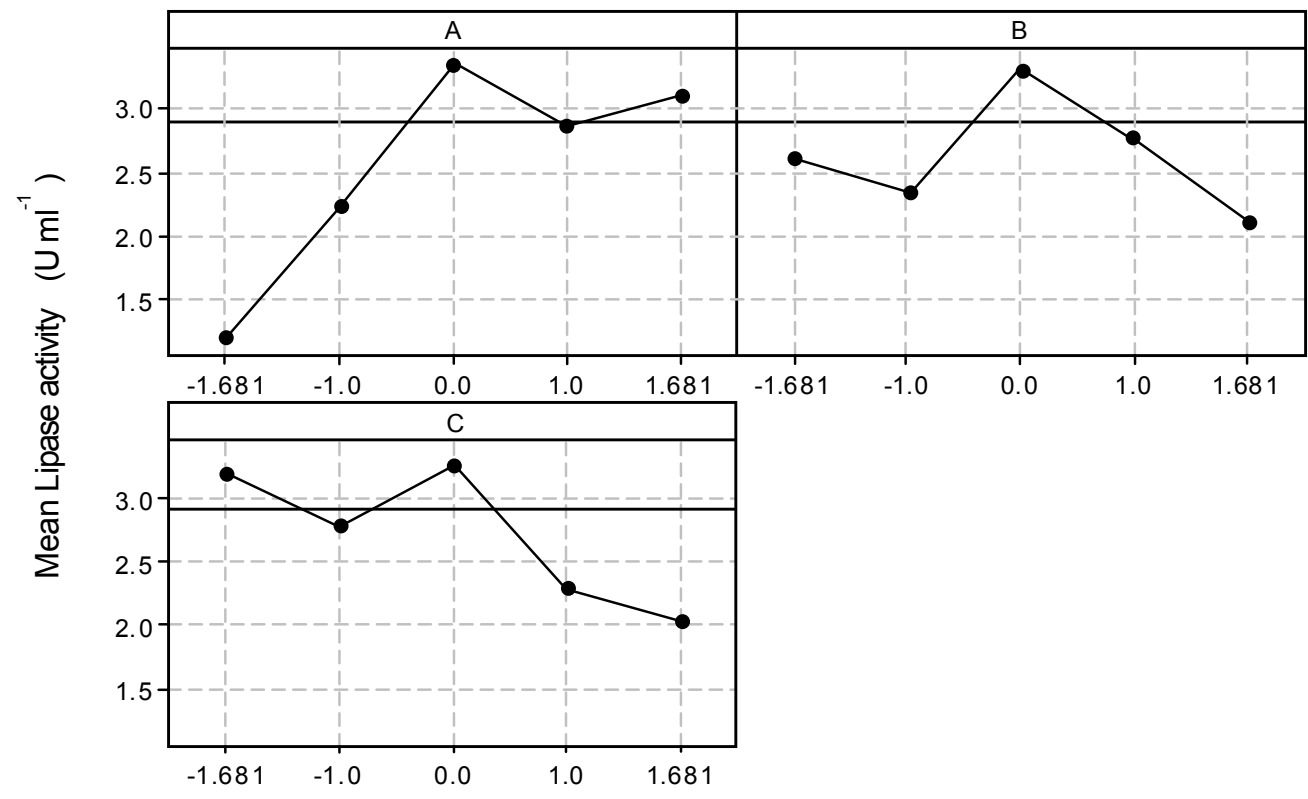

Coded experimental range of independent variables

Figure 4: Main effects plot for lipase production by $R$. arrhizus with the fermentation conditions (A) Temperature, (B) Initial pH, (C) Agitation speed.

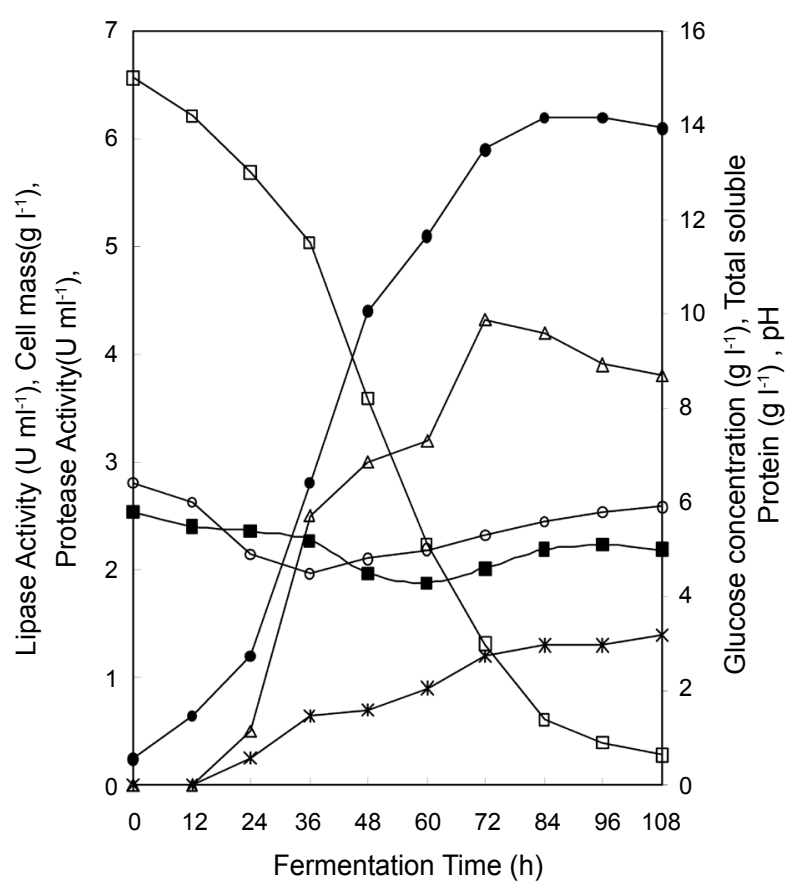

Figure 5: Fermentative production of lipase by R. arrhizus in submerged fermentation. Profile of lipase activity $(\Delta)$, protease activity $(*), \mathrm{pH}(\mathbf{\square})$, cell mass concentration $(\bullet)$, glucose concentration $(\square)$ and total soluble.

exponential phase being a growth associated product. The maximum lipase activity was found in the late exponential phase and early stationary growth phase of $R$. arrhizus. The lipase activity was found to decrease after $72 \mathrm{~h}$ of fermentation, which may be due to the prod- uct inhibition such as the formation of more protease enzyme at the post exponential growth phase of the microorganism or due to the non availability or less availability of inducer oil and the carbon source in the fermentation medium or may be due to the accumulation of fatty acids. Thermal deactivation and digestion of lipases by proteases were prevented due to the presence of vegetable oil inducers in the fermentation medium [29]. The cell mass concentration reached a maximum of $6.2 \mathrm{~g} / \mathrm{L}$ at $84 \mathrm{~h}$ during the stationary phase and there was no further increase in the cell mass concentration after $84 \mathrm{~h}$. The maximum protease activity of $1.4 \mathrm{U} / \mathrm{mL}$ at $108 \mathrm{~h}$ of the fermentation was obtained at the stationary phase of the microorganism. The rate of lipase production was found to be much greater than the rate of protease production. The total soluble protein was found to decrease gradually till $36 \mathrm{~h}$ of fermentation due to the consumption of medium components containing proteins by the microorganism for its growth and metabolic formation and was found to increase from $36 \mathrm{~h}$ to $108 \mathrm{~h}$ due to the secretion and accumulation of various proteins and enzymes in the medium. The $\mathrm{pH}$ of the medium was found to decrease gradually from the initial $\mathrm{pH}$ of 5.9 to $\mathrm{pH} 4.3$ at $60 \mathrm{~h}$ during the exponential phase and the $\mathrm{pH}$ increases from $\mathrm{pH} 4.3$ to $\mathrm{pH} 5$ during the stationary phase of the microorganism. The decrease in the $\mathrm{pH}$ might be due to some organic acid production during the enzyme production and free fatty acid production by $R$. arrhizus and the increase in $\mathrm{pH}$ might be due to the production of free amino acid [30]. The rate of glucose utilization by the microorganism was found to increase rapidly after $12 \mathrm{~h}$ of the fermentation when the microorganism reaches the mid exponential phase. The rate of glucose utilization was directly proportional to the biomass production at any instant and $95.6 \%$ of the glucose was consumed at the end of the fermentation at $108 \mathrm{~h}$, and maximum lipase production was obtained at $72 \mathrm{~h}$ of fermentation.

A well-trained artificial neural network was employed for the prediction of lipase production by Rhizopus arrhizus under various fer- 
mentation conditions. The developed neural network model using the experimental data obtained from CCD gave better predictions when compared to RSM model in predicting the lipase activity and cell mass. It was found that the neural network predictions were very close to the actual experimental values. A relatively good fit of the experimental data predicted by ANN was clearly evident from Figure 3B with $\mathrm{R}^{2}$ values of 0.987 for lipase production.

Multiple regression analysis of the experimental data for cell mass production gives the following second order polynomial equation 22 ,

$$
\begin{aligned}
& \mathrm{Y}_{2}=5.139+0.59 x_{1}-0.5141 x_{2}-0.787 x_{3}-0.651 x_{1}^{2}-0.272 x_{2}^{2}- \\
& 0.0288 x_{3}^{2}-0.008 x_{1} x_{2}-0.588 x_{1} x_{3}+0.131 x_{2} x_{3}
\end{aligned}
$$

where $\mathrm{Y}_{2}$ is the response variable the cell mass and $x_{1}, x_{2}$ and $x_{3}$ are the coded values of the independent variables, temperature, $\mathrm{pH}$ and agitation speed respectively. Both the RSM and ANN models predicted the experimental lipase activity and cell mass extremely well with high $\mathrm{R}^{2}$ value and the ANN predictions are more accurate than RSM. The experimental results agree closely with the results predicted by regression equation substantiating that the RSM using the statistical design of experiments can be effectively used to optimize the process conditions for lipase production.

\section{Unstructured Kinetic Models for Prediction of Lipase Fermentation}

Various unstructured kinetic models were used to predict the kinetics of lipase fermentation by R. arrhizus. Logistic model for cell growth, Logistic incorporated Luedeking Piret model for lipase production and Logistic incorporated modified Luedeking Piret model for substrate utilization provides an accurate approximation of the fermentation kinetics with high $\mathrm{R}^{2}$ values of $0.997,0.94$ and 0.972 respectively. The value of $\mu_{0}$ is $0.0821 / \mathrm{h}$ for the cell growth model. The value of $\alpha$ and $\beta$ is 0.65 and 0.002 respectively which shows that the lipase production by $R$. arrhizus is growth associated since the magnitude of the growth associated parameter ' $\alpha$ ' is much greater than the magnitude of nongrowth associated parameter ' $\beta$ ' in Luedeking Piret model. The product formation models were able to predict the kinetics of lipase production during the exponential phase of the microorganism accurately. But during the stationary phase, the lipase production models did not predict the lipase activity precisely since the unstructured models did not contain a term for inhibitory action of the protease enzyme during the later stages of the fermentation.

For lipase production by Rhizopus arrhizus from Figure 5 it was observed that the cell growth rate was found to be maximum at $36 \mathrm{~h}$ and the glucose utilization rate was found to be maximum at $48 \mathrm{~h}$ of fermentation time. The lipase production rate was found to be almost constant between 36 to $48 \mathrm{~h}$ of the fermentation and reduced with the reduction in the cell growth rate and reached to zero at $84 \mathrm{~h}$. The cell growth rate declined after $36 \mathrm{~h}$ and the growth rate stopped at $84 \mathrm{~h}$. The increase in cell growth rate is accompanied by the increase in substrate utilization rate and lipase production rate. There was a reduction in substrate utilization rate even when the growth rate of the microorganism reached to zero at $84 \mathrm{~h}$. The substrate utilization rate declined after $48 \mathrm{~h}$ and stopped at the $108 \mathrm{~h}$ of fermentation.

\section{Conclusion}

Response surface methodology was employed to optimize the fermentation conditions temperature, $\mathrm{pH}$ of the fermentation medium and agitation speed. The present study identified the effect of various process parameters on the lipase yield and the lipase production was found to be significantly influenced by temperature, agitation speed, the quadratic effects of temperature, initial $\mathrm{pH}$ and agitation speed and the interactive effects of temperature and agitation speed are significant parameters that affect lipase production. The optimized fermentation conditions for lipase production by $R$. arrhizus using the statistical approach was found to be: Temperature, $32^{\circ} \mathrm{C}$; initial $\mathrm{pH} 6$ and agitation speed, $107 \mathrm{rpm}$. Maximum lipase activity of $4.32 \mathrm{U} / \mathrm{mL}$ and maximum cell mass concentration of $6.2 \mathrm{~g} / \mathrm{L}$ was obtained at $72 \mathrm{~h}$ and $84 \mathrm{~h}$ respectively. The experimental results and RSM model predictions shows that the response surface methodology can be successfully used to optimize and to study the interaction effect among the fermentation conditions for lipase production.

\section{Acknowledgments}

The authors gratefully acknowledge the Chemical Engineering Department, Annamalai University for providing the facilities to carry out

\begin{tabular}{|c|c|}
\hline$x_{\mathrm{i}}$ & Coded value of an independent variable \\
\hline $\mathrm{X}_{\mathrm{i}}$ & Real value of an independent variable \\
\hline $\mathrm{X}_{\mathrm{c}}$ & $\begin{array}{l}\text { Real value of an independent variable at the cen- } \\
\text { ter point }\end{array}$ \\
\hline$\Delta \mathrm{X}_{\mathrm{i}}$ & Step change value \\
\hline $\mathrm{Y}_{1}$ & $\mathrm{U} / \mathrm{mL}$ Predicted response (lipase activity) \\
\hline $\mathrm{Y}_{2}$ & g/L Predicted response (cell mass) \\
\hline$\beta_{0}$ & Offset term \\
\hline$\beta_{\mathrm{i}}$ & Coefficient of linear effect \\
\hline$\beta_{\mathrm{ii}}$ & Coefficient of squared effect \\
\hline$\beta_{\mathrm{ij}}$ & Coefficient of interaction effect \\
\hline$a_{i}$ & Input signal \\
\hline$y_{j}$ & Fired output signal \\
\hline $\mathrm{w}_{\mathrm{ij}}$ & Weight associated with the input signal $a_{i}$ \\
\hline$\theta_{j}$ & Threshold value of neuron $\mathrm{j}$ \\
\hline$d_{j}$ & Desired output from neuron $\mathrm{j}$ \\
\hline$\theta$ & Positive constant controlling the speed of learning \\
\hline$\mu_{0}$ & $1 / \mathrm{h}$ Initial specific growth rate \\
\hline $\mathrm{X}_{0}$ & $\mathrm{~g} / \mathrm{L}$ Initial cell mass concentration \\
\hline $\mathrm{X}_{\max }$ & $\mathrm{g} / \mathrm{L}$ Maximum cell mass concentration \\
\hline $\mathrm{X}(\mathrm{t})$ & $\mathrm{g} / \mathrm{L}$ Cell mass concentration at any time ' $\mathrm{t}$ ' \\
\hline$\mu_{\max }$ & 1/h Maximum specific growth rate \\
\hline S & $\mathrm{g} / \mathrm{L}$ Concentration of the limiting substrate \\
\hline$\alpha$ & $\mathrm{gP} / \mathrm{gX}$ Growth associated parameter \\
\hline$\beta$ & $\mathrm{gP} / \mathrm{gX} \cdot \mathrm{h}$ Non-growth associated parameter \\
\hline$\gamma, \eta$ & Constants in the modified Luedeking-Piret model \\
\hline $\mathrm{P}_{0}, \mathrm{P}_{\mathrm{t}}$ & $\begin{array}{l}\mathrm{U} / \mathrm{mL} \text { Product concentrations at initial time and } \\
\text { at anytime 't' respectively }\end{array}$ \\
\hline $\mathrm{S}_{0}, \mathrm{~S}_{\mathrm{t}}$ & $\begin{array}{l}\mathrm{g} / \mathrm{L} \text { Substrate concentrations at initial time and at } \\
\text { anytime ' } \mathrm{t} \text { ' respectively }\end{array}$ \\
\hline
\end{tabular}
this research work. 
Citation: Rajendran A, Thangavelu V (2012) Application of Central Composite Design and Artificial Neural Network for the Optimization of Fermentation Conditions for Lipase Production by Rhizopus arrhizus MTCC 2233. J Bioprocess Biotechniq 2:118 doi: 10.4172/2155-9821.1000118

$\begin{array}{ll}\mathrm{Y}_{\mathrm{X} / \mathrm{S}} & \begin{array}{l}\text { Yield coefficient of cell mass with respect to sub } \\ \text { strate }\end{array} \\ \mathrm{Y}_{\mathrm{P} / \mathrm{S}} & \begin{array}{l}\text { Yield coefficient of product with respect to sub } \\ \text { strate }\end{array} \\ \mathrm{Y}_{\mathrm{P} / \mathrm{X}} & \begin{array}{l}\text { Yield coefficient of product with respect to cell } \\ \text { mass }\end{array} \\ \mathrm{dX} / \mathrm{dt} & \mathrm{g} / \mathrm{L} \cdot \mathrm{h} \text { Cell growth rate } \\ \mathrm{dP} / \mathrm{dt} & \mathrm{U} / \mathrm{mL} \cdot \mathrm{h} \text { Product formation rate } \\ \mathrm{dS} / \mathrm{dt} & \mathrm{g} / \mathrm{L} \cdot \mathrm{h} \text { Substrate utilization rate } \\ \mathrm{K}_{\mathrm{e}} & \text { Maintenance coefficient for cells }\end{array}$

\section{References}

1. Jaeger KE, Ransac S, Dijkstra BW, Colson C, van Henrel M, et al. (1994) Bacterial lipases. FEMS Microbiol Rev 15: 29-63.

2. Ghosh PK, Saxena RK, Gupta R, Yadav RP, Davidson S (1996) Microbial lipases: production and applications. Sci Prog 79: 119-157.

3. Pandey A, Benjamin S, Soccol CR, Nigam P, Krieger N, et al. (1999) The realm of microbial lipases in Biotechnology. Biotechnol Appl Biochem 29: 119-131.

4. Aravindan $\mathrm{R}$, Anbumathi $\mathrm{P}$, Viruthagiri $\mathrm{T}$ (2007) Lipase applications in the food industry. Indian J Biotechnol 6: 141-158.

5. Jaeger KE, Reetz MT (1998) Microbial lipases form versatile tools for biotechnology. Trends Biotechnol 16: 396-403.

6. Yang XH, Wang BW, Cui FN, Tan TW (2005) Production of lipase by repeated batch fermentation with immobilized Rhizopus arrhizus. Process Biochem 40: 2095-2103.

7. Elibol M, Ozer D (2002) Response surface analysis of lipase production by freely suspended Rhizopus arrhizus. Process Biochem 38: 367-372.

8. D'Annibale A, Sermanni GG, Federici F, Petruccioli M (2006) Olive-mill wastewaters: a promising substrate for microbial lipase production. Bioresour Technol 97: 1828-1833.

9. Kalil SJ, Maugeri F, Rodrigues MI (2000) Response surface analysis and simulation as a tool for bioprocess design and optimization. Process Biochem 35 : 539-550.

10. Rojan PJ, Rajeev KS, Madhavan Nampoothiri K, Pandey A (2007) Statistical optimization of simultaneous saccharification and $L(+)$-lactic acid fermentation from cassava bagasse using mixed culture of Lactobacilli by response surface methodology. Biochem Eng J 36: 262-267.

11. Ezequiel FL, Hannes L, Dirk WB (2006) Evaluation of artificial neural networks for modelling and optimization of medium composition with a genetic algorithm. Process Biochem 41: 2200-2206

12. Zorzetto LFM, Maciel Filho R, Wolf-Maciel FR (2000) Processing modelling development through artificial neural networks and hybrid models. Comput Chem Eng 24: 1355-1360.

13. Chandrasekhar K, Arthur Felse P, Panda T (1999) Optimization of temperature and initial $\mathrm{pH}$ and kinetic analysis of tartaric acid production by Gluconobacter suboxydans. Bioprocess Biosyst Eng 20: 203-207.

14. Ghaly AE, Kamal M, Correia LR (2005) Kinetic modeling of continuous submerged fermentation of cheese whey for single cell protein production. Bioresour Technol 96: 1143-1152.

15. Ota Y, Yamada K (1966) Lipase form Candida paralipolytica part I. Anionic surfactant as the essential activator in the systems emulsified by polyvinyl alcohol. Agric Biol Chem 30: 351-358.

16. Anson ML (1938) The estimation of pepsin, trypsin, papain and cathepsin with hemoglobin. J Gen Physiol 22: 79-89.

17. Miller GL (1959) Use of dinitrosalicylic acid reagent for determination of reducing sugar. Anal Chem 31: 426-428.

18. Lowry OH, Rosenbrough MJ, Farr AL, Randell RJ (1951) Protein measurement with folin phenol reagent. J Biol Chem 193: 265-275.
19. Chakravarti R, Sahai V (2002) Optimization of compactin production in chemically defined production medium by Penicillium citrinum using statistical methods. Process Biochem 38: 481-486.

20. Box GEP, Hunter WG, Hunter JS (1978) Statistics for Experimenters: An Introduction to Design, Data Analysis, and Model Building, 1st Ed. John Wiley and Sons, New York, pp 30-85.

21. Cochran WG, Cox GM (1957) Experimental Designs, 1st Ed. John Wiley and Sons, New York, pp. 85-100.

22. Gawande BN, Patkar AY (1999) Application of factorial designs for optimization of cyclodextrin glycosyltransferase production from Klebsiella pneumoniae pneumoniae AS-22. Biotechnol Bioeng 64: 168-173.

23. Dutta JR, Dutta PK, Banerjee R (2004) Optimization of culture parameters for extracellular protease production from a newly isolated Pseudomonas $\mathrm{sp}$. using response surface and artificial neural network models. Process Biochem 39: 2193-2198

24. Linko S, Luopa J, Zhu YH (1997) Neural networks as 'software sensors' in enzyme production. J Biotechnol 52: 257-266.

25. Weiss RM, Ollis DF (1980) Extracellular microbial polysaccharides I. Substrate biomass and product kinetic equations for batch Xanthan gum fermentation Biotechnol Bioeng 22: 859-873.

26. Young TB, Bruley DF, Bungay HR (1970) A dynamic mathematical model of the chemostat. Biotechnol Bioeng 12: 747-769.

27. Luedeking R, Piret EL (1959) A kinetic study of the lactic acid fermentation Batch process at controlled $\mathrm{pH}$. Biotechnol Bioeng 1: 393-412.

28. Dalmau E, Montesinos JL, Lotti M, Casas C (2000) Effect of different carbon sources on lipase production by Candida rugosa. Enzyme Microb Technol 26 : 657-663.

29. Chen SJ, Cheng CY, Chen TL (1998) Production of an alkaline lipase by Acinetobacter radioresistens. J Ferment Bioeng 86: 308-312.

30. Singh J, Vohra RM, Sahoo DK (2004) Enhanced production of alkaline protease by Bacillus sphaericus using fed-batch culture. Process Biochem 39 1093-1101. 